\title{
The Contribution of Greenhouse Gas Emissions on Future Acid Rain in States of Gulf Cooperation Council: Measures to Adopt
}

\author{
Sajjad Ahmad Siddiqi ${ }^{*}$, Basim Al Farsi² \\ ${ }^{1}$ Department of Civil and Architectural Engineering, College of Engineering, Sultan Qaboos University, Al Khould, Muscat, Oman \\ ${ }^{2}$ Department of Physics, College of Science, Sultan Qaboos University, Al Khould, Muscat, Oman \\ Email: *sajjad.wateen@gmail.com
}

How to cite this paper: Siddiqi, S. A., \& $\mathrm{Al}$ Farsi, B. (2019). The Contribution of Greenhouse Gas Emissions on Future Acid Rain in States of Gulf Cooperation Council: Measures to Adopt. Journal of Geoscience and Environment Protection, 7, 82-98. https://doi.org/10.4236/gep.2019.74006

Received: December 29, 2018

Accepted: April 15, 2019

Published: April 18, 2019

Copyright () 2019 by author(s) and Scientific Research Publishing Inc. This work is licensed under the Creative Commons Attribution International License (CC BY 4.0).

http://creativecommons.org/licenses/by/4.0/

\section{Open Access}

\begin{abstract}
Air pollution is one of the serious problems facing the world. This is mainly due to production and consumption of fossil fuels. Sulphur dioxide $\left(\mathrm{SO}_{2}\right)$ and oxides of nitrogen $\left(\mathrm{NO}_{\mathrm{x}}\right)$ emissions could affect human health and destroy vegetation through acid deposition and cause transboundary air pollution. Currently, there are no regional ambient $\mathrm{SO}_{2}$ and $\mathrm{NO}_{\mathrm{x}}$ regulations and control measures of many developing countries including GCC countries. This paper reviewed the experiences of the past acid rain pollution problems in United States, Canada, Europe, Japan and China. In addition, the plausible control measures through application of air pollution abatement technologies, market based regulations were discussed. The study recommended that suitable and locally based measures could be adopted by GCC states to prevent future occurrence of acid rain within the region and beyond.
\end{abstract}

\section{Keywords}

GHG Emission, Air Pollution, Acid Rain, GCC States, Market Based Approach

\section{Introduction}

Air pollution has been one of the major concerns for many countries due to its detrimental effects on human's health, ecosystem and economy. Air pollution occurs when substances like carbon dioxide $\left(\mathrm{CO}_{2}\right)$, sulfur dioxide $\left(\mathrm{SO}_{2}\right)$, nitrogen oxides $\left(\mathrm{NO}_{\mathrm{x}}\right)$, carbon monoxide $(\mathrm{CO})$, Volatile Organic Compounds (VOCs), particulates, and Chlorofluorocarbons (CFCs) are released to the atmosphere either by natural processes or human activities (US EPA, 2017a). Ex- 
posure to these pollutants is associated with health effects such as respiratory infections, heart diseases and cancer (Brunekreef \& Holgate, 2002). Also, air pollutants can cause a variety of environmental problems including climate change, acid rain, crop and forest damage, ozone depletion, effects on wildlife, haze and eutrophication (Lekeshmanaswamy, 2012). However, the effect of this pollution creates heavy costs which are estimated to reach up to $\$ 5$ trillion per annum to treat people and repair the environmental damage (World Bank, 2016). Therefore, researchers continue to work along with governments and environmental agencies to reduce air pollution and the damage it causes.

One of the environmental consequences of air pollution is acid deposition/rain. In simple words, acid rain is a form of precipitation (e.g. snow, fog, sleet, dry materials or rain), containing high concentration of acid forming substances like $\mathrm{SO}_{2}$ and $\mathrm{NO}_{\mathrm{x}}$ which has been released into the atmosphere. In the air, these two chemical compounds react with water molecules or get mixed with the dust forming the acid rain which falls as a dry or wet deposition (US EPA, 2017a; US EPA, 2017b; Mokhtar et al., 2014). $\mathrm{SO}_{2}$ and $\mathrm{NO}_{\mathrm{x}}$ can be formed by natural process like lightening and volcanic eruptions. However, many studies have shown that acid rain formation has been accelerated by human activities (US EPA, 2017a). These include combustion of fossil fuels, power plants, factories (i.e. iron and steel production) utility plants and vehicles.

Acid rain precursors $\left(\mathrm{SO}_{2}, \mathrm{NO}_{\mathrm{x}}\right)$ and ammonia $\left(\mathrm{NH}_{3}\right)$ may form secondary pollutants such as particles and nitrogen species which may react with organic compounds to contribute form ozone $\left(\mathrm{O}_{3}\right)$ (Menz \& Seip, 2004). Ozone results from photochemical reaction between oxides of nitrogen and volatile atmospheric compounds, these volatile compounds are mainly emitted by industries and transportation sector (Schmieman et al., 2002).

When acid rain falls, it can cause detrimental effects to the ecosystem. It can acidify the soil and depletes nutrients as well as mobilize aluminum and other toxic metals which can be absorbed by plants or reach water bodies. This ultimately can reduce fish population (Krug \& Frink, 2010). Buildings and cultural heritage arts, especially those built from limestone, are also affected by acid rain. Acidic depositions can damage the paint, corrodes and accelerates the deterioration of artifacts. Exposure to fine particulates from acid depositions can result into health effects like asthma and bronchitis (Larssen \& Carmichael, 2000). However, the problem of acid rain predominates industrialized countries like United States, Canada, Europe and China. But it is important to keep in mind that country's emissions of $\mathrm{SO}_{2}$ and $\mathrm{NO}_{\mathrm{x}}$ do not only affect the local environment but rather are transported to other countries by meteorological conditions (wind direction and speed) (Menz \& Seip, 2004).

Bilateral negotiations over transboundary pollution have a long history. At the beginning of the twentieth century, a Canadian firm was accused of polluting United States with lead and zinc. This led into creation of North American Agreement on Environmental Cooperation (NAAEC) among the United States, 
Canada and Mexico with the aim of treating several environmental Issues including transboundary pollution (Rótulo \& de Oliveira, 2008). In Europe, the convention on Long Range Transboundary Air Pollution (CLRTAP) took many years and was sign by 30 countries in 1979. Similarly, China and Japan has initiated a transboundary acid rain program to combat the damage of acid rain on both countries. Without any doubt, this would make these countries the leading figures in policy making, technology and advancement in mitigating acid rain effects. Hence, countries like the Gulf Cooperation Council (GCC) have to learn from this experience.

The rapid economic growth of the GCC may lead into high greenhouse gases emissions along with $\mathrm{SO}_{2}$ and $\mathrm{NO}_{\mathrm{x}}$. If no action is to be taken to anticipate and control $\mathrm{SO}_{2}$ and $\mathrm{NO}_{x}$, the GCC countries might end by facing consequences of acid rain. To date, there are limited literatures addressing acid rain in most developing countries. Therefore, the objective of this paper is to review Acid Rain $\left(\mathrm{SO}_{2}\right.$ and $\left.\mathrm{NO}_{\mathrm{x}}\right)$ emissions regulations and programs adopted by United States, Canada, Europe and China. The study will also recommend to GCC member states on strategies and measures needed to combat future transboundary $\mathrm{NO}_{\mathrm{x}}$ and $\mathrm{SO}_{2}$ emissions within the region.

\section{Method}

A literature review was conducted greenhouse gas and acidic in GCC countries by employing several scientific databases. In addition, grey literature search was also explored to acquire data from government agencies such as United States Environmental Protection Agency. The search terms including: "acid rain in GCC" or "greenhouse gases in GCC", or " $\mathrm{SO}_{2}$ emissions in GCC" and " $\mathrm{NO}_{x}$ emission in GCC". In addition, terms of acquiring literature outside GCC region were also included in the search. These includes: "acid rain in United States" or "acid rain in China" or "acid rain in Japan" or "acid rain control" and " market based approach". Indoor, greenhouse gases, $\mathrm{SO}_{2}$ and $\mathrm{NO}_{\mathrm{x}}$ emissions were excluded from the search. Due to limited studies on this topic, the search was limited to about 30 published papers. The paper first presents the overview of the acid rain control strategies through market based and technological approach followed by the acid rain experiences by China, Japan, Canada, and United States. Later, acidic gases emissions in GCC countries will be discuss including policies and programs of controlling future occurrence of acid rain in the region.

\section{Examples of Tools Used in Acid Rain Control}

Countries who have suffered from acid rain problems have learnt from their experiences. They have developed a rigorous policies and technologies to control and mitigate the detrimental damage of acid rain. This includes economic instruments such as market based pollution control tools, and abatement technologies including setting caps for pollution concentration levels. 


\subsection{Application of Market Based Pollution Control Tools}

Emission trading is widely accepted economic instrument to environmental externalities (Lee \& Zhou 2015). Emission trading builds up the market incentive and achieves the cost effectiveness, thus the benefits obtained from trading between parties will be larger than the benefit derived from individual emission reduction (Lee \& Zhou 2015).

Following polluter-pay principle, policy making goal is to internalize externalities through market-based instruments such as emission trading schemes and taxes as well as command and control measures (Bachmann \& van der Kamp 2014). In recent years, the use of tradable emission permits as a market based environmental policy instruments has gained increasing attention by both policy makers and regulators in a lot of countries.

Firms can buy or sell emission allowances so that those with least opportunity cost to reduce emissions will have an incentive to do so, and they receive compensation by selling their excess allowances to others who emit above.

Trading emission allowances, according to economic taught, would equalize marginal abatement cost among generating units, and this should limit $\mathrm{SO}_{2}$ emissions at a lower cost than traditional command-and-control approaches (Ellerman, 2002). For emission trading mechanism, it would be helpful if the regulator is able to predict, for any imposed emission cap, the approximate equilibrium trading price and the resulting emissions from each polluter. This may help the regulator to set an appropriate cap and devise a reasonable initial allocation, the benefit of well-balance allocation initial allocation could be substantial. This is because it can reduce both the transaction costs and the time for the market to reach equilibrium (Li et al., 2015).

Emission standard requires a legal limit on an amount of pollutant of which individual source is allow emitting, when emission standards are the policy of choice, there is no reason to believe that the authority will assign the responsibility of emissions reduction in a cost-minimizing way. Unlike emission charge, they are normally fee collected by government which is levied on each unit of pollutant emitted into the air. The total payment any sources would make to government could be determined by multiplying the fee times the amount of pollution emitted (Tietenberg \& Lewis, 2012).

Economic generally concur that market-based approaches are the most cost effective approach for reducing pollution certain sectors than command-and-control regulation. This conclusion is based on the assumption that a market based approach will constantly coordinate the behavior of relevant parties through within the market established to reduce pollution. Thus, the price could be determined endogenously by the market or set exogenously as a pollution tax rate, either ways; the marginal cost to abate pollution will be equated across all market participants. However, if the market produces prices such for in a cap-and-trade program that do not represent the marginal cost of pollution reduction, the cost effectiveness augment in favor of market-based approaches may no longer be accurate (Hitaj \& Stocking, 2016). 


\subsection{Air Pollution Abatement Technologies}

Dedicated $\mathrm{NO}_{\mathrm{x}}$ emission reducing technologies can be divided into combustion and post combustion technologies. Post combustion technologies are an end-of-pipe solution that reduces $\mathrm{NO}_{\mathrm{x}}$ in flue gases after the combustion stage, either through catalytic or non-catalytic reduction of $\mathrm{NO}_{\mathrm{x}}$ compounds. Selective catalytic reduction (SCR) uses ammonia or urea to reduce $\mathrm{NO}_{\mathrm{x}}$ into water and molecular nitrogen $\left(\mathrm{N}_{2}\right)$ on catalytic bed at lower temperature.

SCR is very efficient in reducing $\mathrm{NO}_{\mathrm{x}}$ emissions but its installation is expensive. Selective non-Catalytic Reduction (SCNR) on the other hand does not require catalyst and cooling, cooling of the flue gas is therefore cheap but also not efficient. SCR and SCNR contribute to $90 \%$ and $35 \%$ emission reductions respectively. Flue gas condensation technology improves energy efficiency and has been adopted by many of Swedish plants leading to low $\mathrm{NO}_{\mathrm{x}}$ emissions. Japan has developed emission reduction technologies in reducing transboundary air pollutions with China. This was achieved by developing coal washing, to circulating fluidized bed boilers with Sulphur removal, to flue gas desulphurization gas units (Ohshita \& Ortolano, 2012).

The acid rain program was aimed to reduce annual $\mathrm{SO}_{2}$ emissions below 1980 levels, mainly through monitoring and enforcement. Power plants have options to reach compliance by; installing flue-gas desulfurization (FGD), switching to low sulphur coal or natural gas or adopting renewable energy technology.

In the 1990s and 2000s emissions of $\mathrm{SO}_{2}$ has declined drastically and this achievement was due to market based approaches adopted in reducing air pollution which encourages producers or emitters to seek for alternative cost effective technology of reducing their emissions. Researchers have recognized that environmental regulation can be a double-edge sword. Environmental regulations increase firm's cost, such as abatement cost as well as its associated entry and exit, production and investment cost. However, a well-designed environmental regulation induces innovation in green technology and improves environmental and business performance in a long run (Streeter, 2016).

\section{Acid Rain Program in United States}

In 1994, the Acid Rain program (ARP) was enacted with the main goal of reducing annual $\mathrm{SO}_{2}$ emission by $45 \%$ to 1980 levels. The first phase began in 1995 and affected about 110 sources in electricity industry with greatest emissions while the second phase in 2000 affects all the significant emission sources in the electricity sector (Ellerman, 2002). The ARP operating under a system of allowance trading that uses a market based incentive to reduce pollutions provides a regulated source with the flexibility to selects the most cost effective approach to reduce emissions. These have proven to be a highly effective way to achieve emission reductions, meet environmental goals, and improve human health (US EPA, 2016).

Right to emit $\mathrm{SO}_{2}$ was primary given free to electricity generating units (EGUs), 
although small fraction was sold during auctions. Once the allowance is distributed, they could be traded in a secondary market by regulated firms and as well as other parties who registered with the U.S Environmental Protection Agency (EPA).

Firms with caps basically coal burning electricity generators were required to submit yearly allowances to EPA; however, allowances not used for compliance in a particular could be shifted to subsequent year by banking system. There are frequent changes in of price of $\mathrm{SO}_{2}$ allowances as buyers and sellers assessed new information the cost of emission abatement, the demand for electricity and changes in program regulations (Hitaj \& Stocking, 2016). After trades are consummated, they are recorded in EPA electronic Allowance Tracking System, usually within 24 hours of being reported (Ellerman, 2002).

Under the market system, EPA sets a cap on overall emissions, $\mathrm{SO}_{2}$ allowances are then allocated to affected units serving generators greater than 25 megawatts. All new units based on their historic fuel consumption and specific emission rates and each allowance permits a unit to emit one ton of $\mathrm{SO}_{2} \cdot \mathrm{NO}_{\mathrm{x}}$ program embodies many of the same principles of the $\mathrm{SO}_{2}$ trading program, in that it also has a results-oriented approach, flexibility in the method of achieving emission reductions, and program integrity through measurement of the emissions. However, it does not "Cap" $\mathrm{NO}_{\mathrm{x}}$ emissions as the $\mathrm{SO}_{2}$ program, nor does it utilize an allowance trading system (US EPA, 2017b).

However, both $\mathrm{SO}_{2}$ and $\mathrm{NO}_{\mathrm{x}}$ programs seems to work well. This is obvious from the annual reports published by the EPA where the progress reduction of $\mathrm{SO}_{2}$ and $\mathrm{NO}_{\mathrm{x}}$ is clearly depicted in Figure 1 and Figure 2. Units in ARP emitted 3.2 million tons of $\mathrm{SO}_{2}$ in 2014 below the APR's statutory annual cap of 8.95 million tons (Figure 1). APR sources reduced emission by 12.5 million tons (80\%) from 1990 levels and 14.1 million tons (81\%) from 1980 levels. Similarly, Figure 2 shows that the Units in the APR $\mathrm{NO}_{\mathrm{x}}$ program emitted 1.7 million tons of $\mathrm{NO}_{\mathrm{x}}$ in 2014, indicating that APR sources reduced emission by 6.4 million tons from the projected level in 2000 without the APR (Bachmann \& van der Kamp 2014).

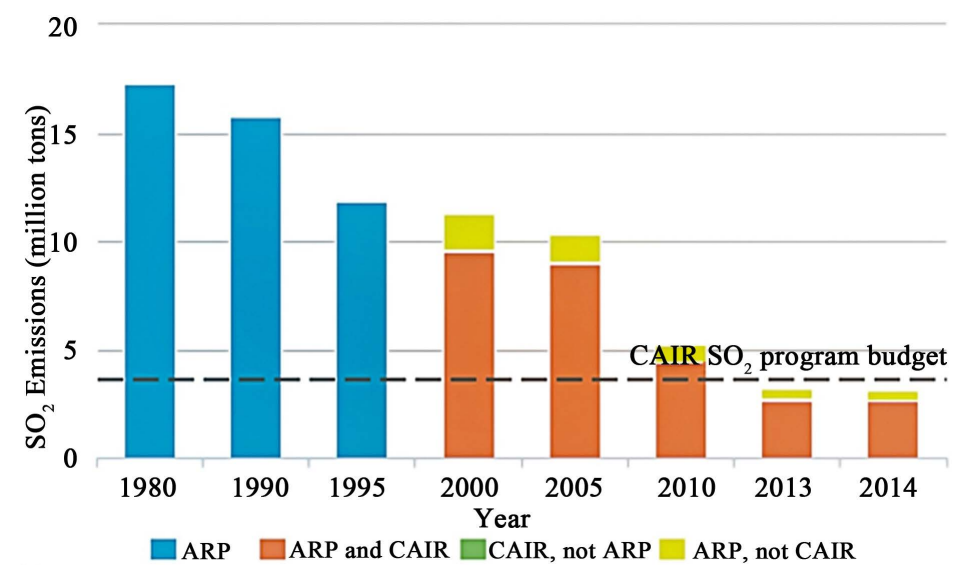

Figure 1. $\mathrm{SO}_{2}$ Emissions from CAIR $\mathrm{SO}_{2}$ Annual Program and ARP 1980-2014 (US EPA, 2017b). 
8

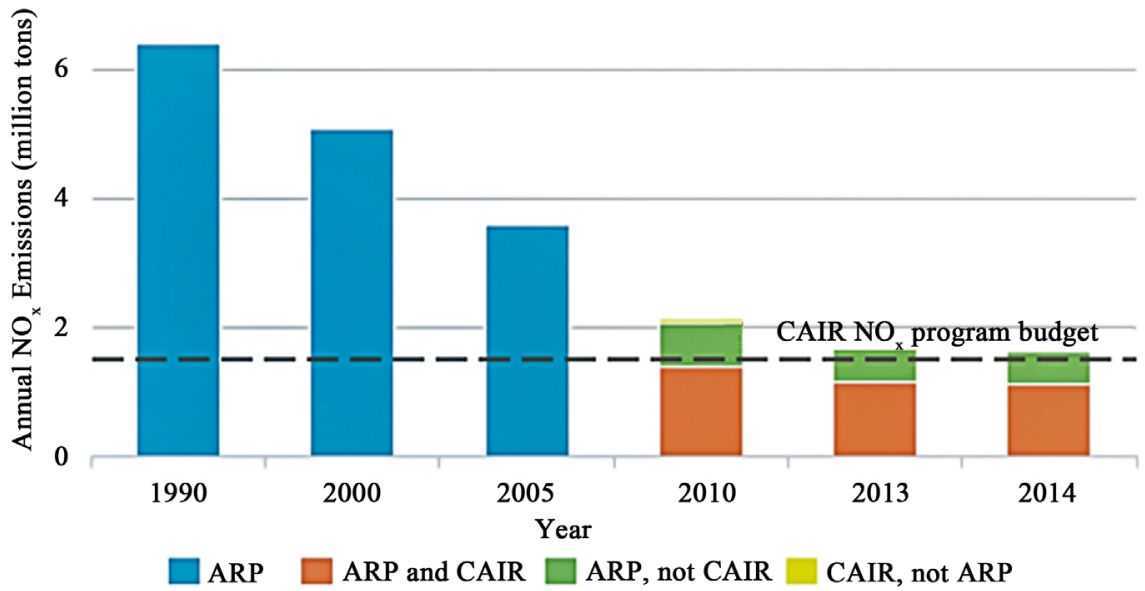

Figure 2. Annual $\mathrm{NO}_{\mathrm{x}}$ Emissions from CAIR and ARP Sources, 1990-2014 (US EPA, 2017b).

\section{United States-Canada Transboundary Acid Rain Program}

Multiple environmental and health problems have been caused by air pollution from mobile and stationary emission sources in Canada and the United States. This is because; both nations have an interest in reducing trans-boundary air pollution. After more than a decade of scientific research and discussion they signed a historic Air Quality Agreement (AQA) in Ottawa, Canada, on March 13, 1991. This agreement established a formal and flexible method of addressing an acid rain as trans-boundary air pollution problem. The Air Quality Agreement includes Annex 1, the acid rain annex, focuses on the commitment of both parties to reduce Sulphur dioxide $\left(\mathrm{SO}_{2}\right)$ and Nitrogen oxides $\left(\mathrm{NO}_{\mathrm{x}}\right)$ emissions which are the primary precursors of the acid rain. Both nations are committed to use Continuous Emission Monitors (CEMs) (Environment Canada, 2017). Under Annex 2, the Scientific and Technical Activities and Economic Research Annex, both nations agree to coordinate their air pollution monitoring networks; the use of compatible formats and methods for monitoring, reporting, cooperation and exchange of information about the causes and effects of $\mathrm{SO}_{2}$ and $\mathrm{NO}_{\mathrm{x}}$ through application of market-based programs (Environment Canada, 2017).

Figure 3 and Figure 4 shows how Canada and United States have been successful in $\mathrm{SO}_{2}$ emissions under their respective acid rain programs. In 2000, Canada's total $\mathrm{SO}_{2}$ emissions of approximately 2.5 million tons were $20 \%$ below the national emission cap commitment of 3.2 million tons. New emission reduction targets have been set for $\mathrm{SO}_{2}$ under Canada-Wide Acid Rain Strategy for Post 2000. $\mathrm{SO}_{2}$ emissions in the United States have been reduced by 6.7 million tons (39\%) compared with the 1980 levels.

In 2012, Canada's total $\mathrm{SO}_{2}$ emissions were 1.3 million metric tons (mmt), about $60 \%$ national cap of $3.2 \mathrm{mmt}$ and this represent a $58 \%$ reduction in Canada's total $\mathrm{SO}_{2}$ emission in 1990 levels. The largest contribution to Canada's 


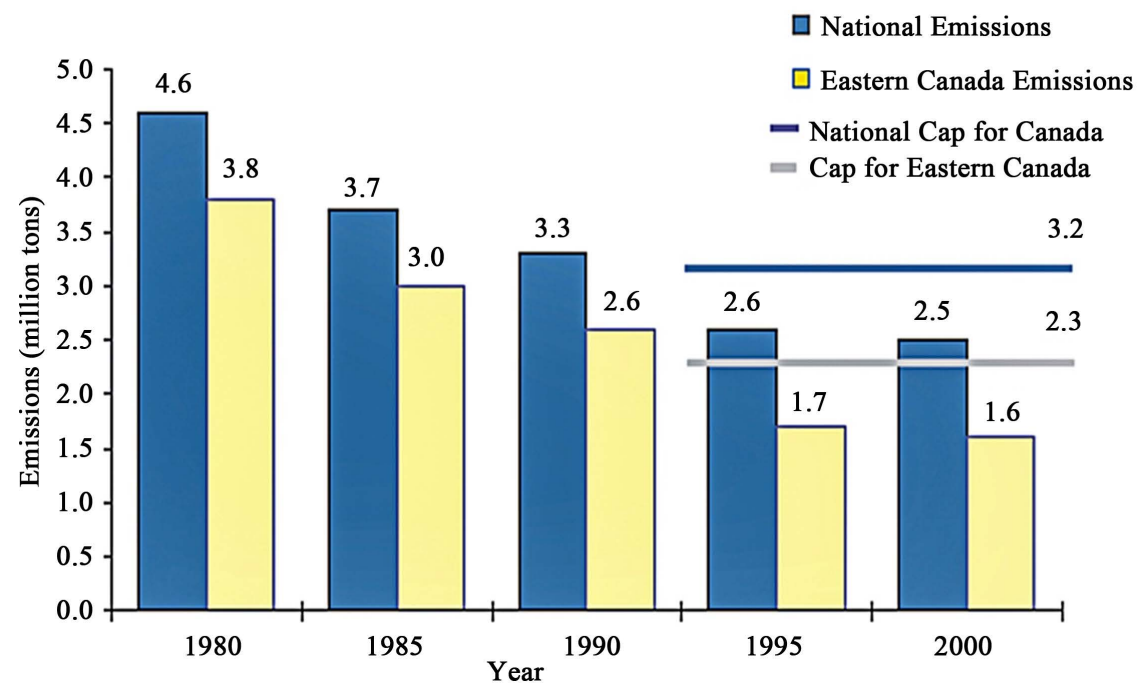

Figure 3. Canada $\mathrm{SO}_{2}$ emissions contributing to acid rain, 1980-2000 (Environment Canada, 2017).

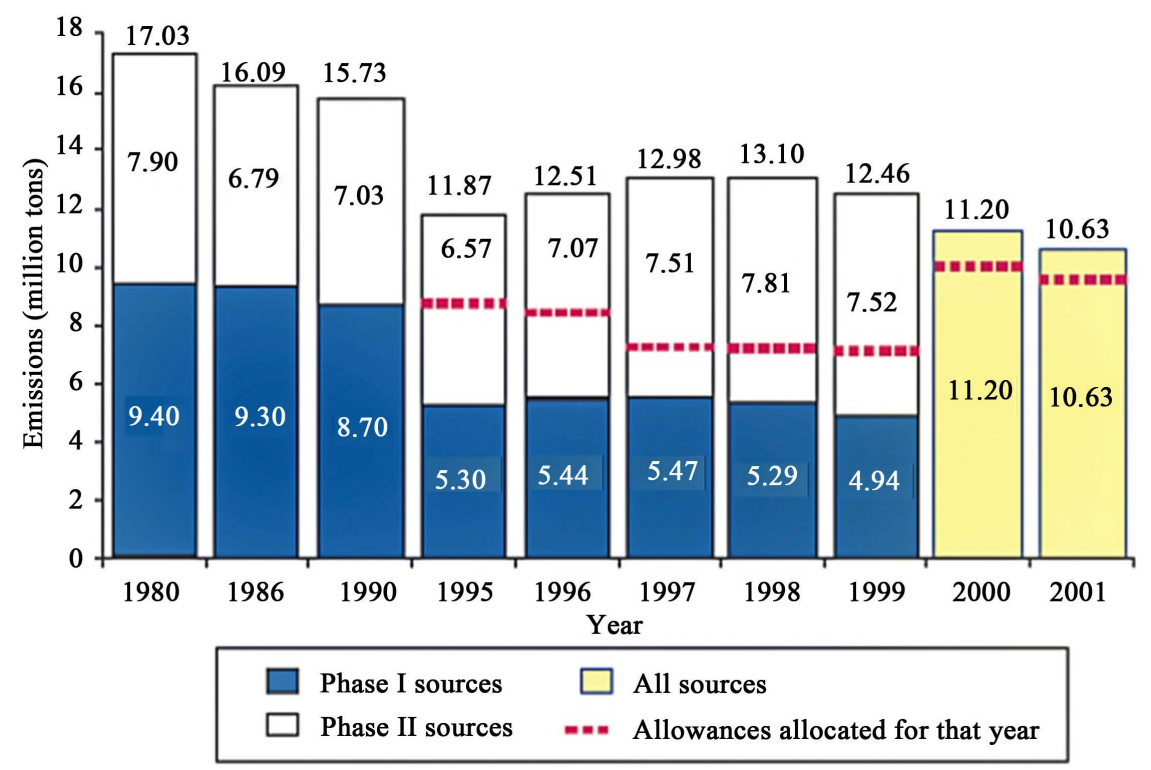

Figure 4. U.S $\mathrm{SO}_{2}$ emissions for phase I and phase II units (US EPA, 2017b).

$\mathrm{SO}_{2}$ emissions originates from industrial sources (non-ferrous smelting and refinery industries, petroleum industries) accounting for $66 \%$ of national $\mathrm{SO}_{2}$ emissions in 2012. In U.S, ARP units emitted $3.0 \mathrm{mmt}$ of $\mathrm{SO}_{2}$ in 2012, this implies that ARP sources reduced by $11.3 \mathrm{mmt}$ which represent $79 \%$ reduction from 1990 levels. The vast majority of $\mathrm{APR} \mathrm{SO}_{2}$ emissions comes from coal-fired EGUs (IJC, 2014).

\section{European Union (EU) Acid Rain Program}

As in the United States, local health effects of air pollution $\mathrm{SO}_{2}$ and $\mathrm{NO}_{\mathrm{x}}$ emissions) were the main issue in Europe until the late 1960s, when the trans-boundary 
nature of acid rain became evident. At United Nations Conference on the $\mathrm{Hu}$ man Environment in Stockholm, a report was presented on the effects of the long-range transport of Sulphur compounds. In the report, it was stated that; "this continental character of the problem caused by emission of Sulphur to the atmosphere implies, as a basis for action, that plans and programs designed to reduce damage from acid deposition must be recognize the fact that, as a rule, several states are involved ... international legislation and control should be contemplated to cope with this problem".

Shortly after the Stockholm conference, the Organization for Economic Cooperation and Development (OECD) launched a program to monitor long-range pollution. In 1978, the OECD monitoring network took the name Cooperative Program for Monitoring and Evaluation of Long-range Transmission of Air Pollutants in Europe (EMEP) (Menz \& Seip, 2004). The necessity of international cooperation in dealing with acidification problems in Europe led to the "Convention on Long Range Transboundary Air Pollution" (LRTAP). The LRTAP convention entered into force in 1983 was the first legally binding international agreement to deal with problems of air pollution (mainly $\mathrm{SO}_{2}, \mathrm{NO}_{\mathrm{x}}, \mathrm{VOC}, \mathrm{NH}_{3}$, Heavy metals etc.) on broad basis. In addition to air pollution abatement, the Convention established institutional frame work bringing together science and policy (Menz \& Seip, 2004).

The implementation of the recommendations of this directive led into reduction in $\mathrm{SO}_{2}$ and $\mathrm{NO}_{\mathrm{x}}$ in air. In 1996, EU passed a new the Directive on Ambient Air Quality Assessment and Management, this set out a new requirement regarding air quality. These actions aimed at preventing or limiting harmful effect on human health and the environment. It also contains recommendations regarding air quality assessment methods and criteria, common to all member states, but unfortunately this directive failed. In few years later, EU passed four Daughter Directives, among the first Daughter Directive of the four is on permissible levels of $\mathrm{SO}_{2}, \mathrm{NO}_{x}$, dust and Lead which was passed in 1999, this directive sought to protect human health and the ecosystem. The EU has also introduced emission reduction of pollutants from both stationary (power plants) and mobile (motor vehicles) sources which was passed in 2001. These mandates set a permissible level of pollutant emissions from large coal-fired power generating plants. The main objective is to gradually reduce annual emission of $\mathrm{SO}_{2}$ and $\mathrm{NO}_{\mathrm{x}}$ from existing installations. It also specifies permissible emissions of $\mathrm{SO}_{2}$ and $\mathrm{NO}_{\mathrm{x}}$ from existing installations, and also specifies to specify permissible emissions of $\mathrm{SO}_{2}, \mathrm{NO}_{\mathrm{x}}$ and dust for the existing and new incinerators with regards to motor vehicles. Table 1 shows pollutants emission standard on cars for $\mathrm{NO}_{\mathrm{x}}$ and Particulate matter.

Irrespective of the measures taken and the consequent considerable improvement in air quality, the harmful effects of air pollution were not reduced. During the Sixth Environment Action Program (EAP) of the European Community, a new measure was devised for achieving levels of air quality that would no longer pose threat to human health and the natural environment. This led to evolution 
Table 1. Emissions standards on cars for $\mathrm{NO}_{\mathrm{x}}$ and PM (Landgrebe et al., 2008).

\begin{tabular}{ccccc}
\hline \multirow{2}{*}{ Emission standards/Regulations } & \multicolumn{2}{c}{$\mathrm{NO}_{\mathrm{x}}(\mathrm{mg} / \mathrm{km})$} & \multicolumn{2}{c}{$\mathrm{PM}(\mathrm{mg} / \mathrm{km})$} \\
\cline { 2 - 5 } & Petrol & Diesel & Petrol & Diesel \\
\hline Euro1/91/441/EWG93/59/EWG & - & - & - & $140-180$ \\
Euro 2/94/12/WE and 96/69/WE & - & - & - & $80-100$ \\
Euro 3/98/69/WE & 150 & 500 & - & 50 \\
Euro 4/98/69/WE and 2002/80/WE & 80 & 250 & - & 25 \\
Euro 5/WE No.715/2007 & 60 & 180 & 5 & 5 \\
Euro 6/WE No.715/2007 & 60 & 80 & 5 & 5 \\
\hline
\end{tabular}

of Clean Air for Europe Program (CAFE) which was implemented by European Commission. The aim of this convention is to explore whether the current regulation was sufficient to achieve the objective of the Six EAP by 2020. In 2008, European Parliament and Council on Ambient Air Quality for Europe drew a new regulation which requires EU member states to guarantee that the permissible levels of emissions it sets shall not be exceeded. The permissible levels stipulated in the regulation are the minimum levels each $\mathrm{EU}$ member states must strive to achieve. Table 2 shows EU, air quality standards of some selected pollutants, which is stricter compare U.S and World Health Organization (WHO) standards (Kuklinska et al., 2015).

\section{Acid Rain Program in China}

Acid rain in China is mostly caused by emissions of Sulphur dioxide by power plants, industrial boilers, ore smelters and oil refineries, though smaller stationary combustion sources also contribute to the problem in the urban areas. Coal combustion sources contribute to $94 \%$ of all Sulphur dioxide emissions, with power plants being the largest contributor. This is because stack heights are usually very high and power plant's emissions contribute more to regional acid rain than to local one. Domestic damages caused by Sulphur dioxide emissions in China are substantial and comparable to damages suffered by severely acidified regions in North America and Europe. It is estimated that air pollution causes nearly 4000 deaths per year in Chongqing and Beijing (Nagase \& Silva 2007).

China had air pollution control since 1987, starting with the Air Pollution Prevention and Control Law. This regulation was focused primarily on $\mathrm{SO}_{2}$ in order to address the problem of ever increasing acid rain problems, but did not cover emissions from power plants. The regulation was amended in 1995 to expand the coverage to include power sector. In 1998, a regional control strategy across 27 provinces, was introduced to regulate source-areas responsible for $\mathrm{SO}_{2}$ emissions and effect-areas suffering from acid rain in separate fashion (Dong et al., 2015).

A notable strategy adopted by the Chinese government was to integrate pollution control targets with the national policy; this policy features the Five-Year 
Table 2. Comparison of current Air Quality limits with EU and US (EEA 2017; US EPA 2017b).

\begin{tabular}{ccccc}
\hline \multirow{2}{*}{ Pollutant } & Average time & $\begin{array}{c}\mathrm{EU} \\
(\mathrm{AQS}, 2011)\end{array}$ & $\begin{array}{c}\text { U.S } \\
\text { (U.S EPA, 2012) }\end{array}$ & $\begin{array}{c}\text { WHO } \\
(\text { WHO, 2006) }\end{array}$ \\
\hline & 1 hour mean & 134 & 75 & - \\
$\mathrm{SO}_{2}(\mathrm{ppb})$ & 3 hours mean & - & 500 & - \\
& 24 hours mean & 47 & 140 & 8 \\
& annual mean & - & 30 & - \\
& 1 hour mean & 105 & 100 & 106 \\
$\mathrm{NO}_{2}(\mathrm{ppb})$ & 24 hours mean & - & - & - \\
& annual mean & 21 & 53 & 21 \\
$\mathrm{PM}_{10}$ & 24 hours mean & 50 & 105 & 50 \\
$\left(\mu \mathrm{g} \cdot \mathrm{m}^{-3}\right)$ & annual mean & 40 & - & 20 \\
$\mathrm{PM}_{2.5}$ & 24 hours mean & - & 35 & 25 \\
$\left(\mu \mathrm{g} \cdot \mathrm{m}^{-3}\right)$ & annual mean & 25 & 15 & 10 \\
& 1 hour mean & - & 120 & - \\
Ozone $(\mathrm{ppb})$ & 8 hours mean & 40 & 75 & 50 \\
\hline
\end{tabular}

Planning (FYP) development initiative. This plan allows the central and the local government to set a series of targets regarding their financial, technical, and political progress for the next five years. In the $9^{\text {th }} \mathrm{FYP}$ (1996-2000), the $\mathrm{SO}_{2}$ emission control was introduced and a mitigating target was set for the key sectors and regions. The target is established by the Ministry of Environmental Protection of China and the local environment protection bureaus. This method of pollution controls features a top-down procedure to regulate amount of emissions. The central government set the total emission control (TEC) targets and then disaggregates it into different provinces the provincial government further disaggregates such targets further to cities (Kanada, et al., 2013).

The latest regulation enters into force under the Twelfth Fifth Year Plan (FYP12), this regulation took an effect in January, 2012 and call for further 8\% reduction in $\mathrm{SO}_{2}$ emission to 2010 levels. The regulation was also for the first time calling for and targeting $10 \%$ reduction in $\mathrm{NO}_{\mathrm{x}}$ emissions. Under this control targets, power plants producers are required to adopt abatement technology or shut down the most inefficient power plants. According to officials, the new $\mathrm{SO}_{2}$ and $\mathrm{NO}_{\mathrm{x}}$ regulations requires domestic power generation sector alone to reduce 6.2 million metric tons $(\mathrm{mmt})$ of $\mathrm{SO}_{2}$ and $5.8 \mathrm{mmt}$ of $\mathrm{NO}_{\mathrm{x}}$ emissions (Nam et al., 2013).

To achieve this target, the government employed a market based instruments such as cap and trade as a potential policy tool where the regulator allocates emission permits to polluters who may then trade among themselves. However, the success of the trading scheme was constrained by lack of sufficient administrative capacity, a lagging-behind legal systems and unsatisfactory emission 
measurement accuracy. Lack of national regulation and weak enforcement of planned missions could be an obstacle to implement emission trading successfully (Li et al., 2015).

\section{China-Japan Transboundary Acid Rain Program}

Climate scientist agrees that emissions of Sulphur dioxide in Northeastern China contribute to Sulphur deposition in Western Japan due to unfavorable downwind geographic position of Japan. It is estimate that China's contribution to wet sulphate deposition represents $50 \%$ of the total. Yet, trans-boundary pollution problem will likely become more serious in the future because energy consumption levels in major urban and industrial cities in Northeastern China have been growing rapidly. Also, Chinese energy supplies come mostly from coal-burning power plants. Japan's damages originating from Chinese-produced acid rain may reach catastrophic levels by 2020 (Nagase \& Silva 2007).

Japan on the other hand, has aggressively controlled its own emission of acidic pollutants of over the past 30 years. Laws and regulations to control air pollution were first enacted in 1960s and taxes on Sulphur emissions were also introduced in 1973. Japan has been one of the world leaders in development of desulphurization technology. Both Japan and China went to bi-national agreement on number of air pollution projects to reducing trans-boundary acid rain problems in both nations. This encompasses policy dialogue and consists of four programs: Training, feasibility studies, research cooperation and technology demonstration. Japanese Cleaner Coal Technology (CCT) program was introduced and took place in China in 1993.

According to Ohshita and Ortolano (2012), this is how the bi-national cooperation took place:

The program is carried out through a network of public and private organizations, and it's coordinated by semi-governmental; New Energy and Industrial Technology Development (NEDO). Japanese Ministry of International Trade and Industry (MITI) provides public fund for the program and supports the participation of Japanese organizations, including private firms, industrial association and training organization. Chinese side covers the cost of local construction, management, and operation.

\section{Air Pollution in GCC Countries}

During the last two decades, many countries in Gulf Cooperation Council (GCC) have witness an unprecedented economic growth and infrastructural developments accompanied by oil and natural gas discoveries (Bhutto et al. 2014; Rafindadi et al., 2018). Exploitations in the region for oil and gas, growing energy demand and the overconsumption of energy has increases $\mathrm{SO}_{2}$ and $\mathrm{NO}_{\mathrm{x}}$ emissions and this may be due to industries and vehicles (Farahat, 2016). According to Rafindadi et al. 2018 environmental pollution problems may be exacerbated in GCC as a result of low cost of energy, free taxation and existence of 
high energy demand companies with no effective control measures. Similarly, Bhutto et al. (2014) reported that GCC is rated as one of most highly polluted region due to high per capita $\mathrm{CO}_{2}$ emissions from the region as it accounts for $2.4 \%$ of GHG emissions with as low as $0.6 \%$ of the total global population. Therefore, GCC members are supposed to play a unique and critical role in international environmental policies (Atalay et al., 2016). Table 3 shows energy consumption and $\mathrm{CO}_{2}$ emission levels among the GCC states with Saudi Arabia showing high energy production and $\mathrm{CO}_{2}$ emissions followed by Qatar and UAE, with the least being Bahrain and Oman.

Per capita $\mathrm{CO}_{2}$ emission levels in GCC states in Figure 5 shows that, Qatar and Kuwait are the largest emitters with Saudi Arabia and Oman are low. Thus, $\mathrm{CO}_{2}$ emission potential of a country is not only a function of energy production, consumption but also number of population, this are one of the factor that places GCC is one of highest global emitters of $\mathrm{CO}_{2}$.

Since $\mathrm{CO}_{2}$ levels is an indicator of economic activity, it may be directly related to level of atmospheric pollution level of a particular country if rigorous ambient air pollution control policies are not instituted. According to Chavez-Baeza \& Sheinbaum-Pardo (2014), $\mathrm{SO}_{2}$ and $\mathrm{NO}_{\mathrm{x}}$ depends purity of the fossil fuels, thus high sulfur containing fuels may lead high emissions of ambient air pollutants if appropriate technologies are not employed by the industries. Since the principal source of energy production and consumption in GCC are fossil fuel, ambient

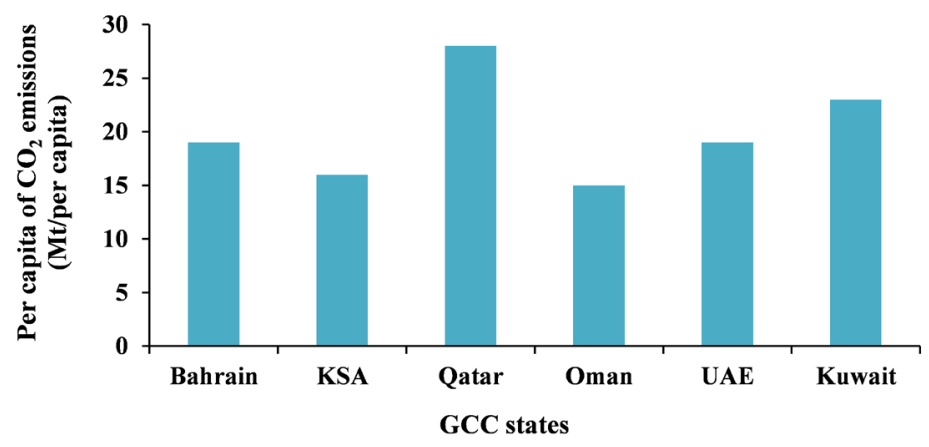

Figure 5. Per capita $\mathrm{CO}_{2}$ emission levels in GCC countries for 2014 (IEA, 2013).

Table 3. Energy consumption and $\mathrm{CO}_{2}$ emission data in GCC states in 2014 (IEA, 2013).

\begin{tabular}{cccccc}
\hline Country & $\begin{array}{c}\text { Energy } \\
\text { production (Mtoe) }\end{array}$ & $\begin{array}{c}\text { Energy } \\
\text { consumption (TWh) }\end{array}$ & $\begin{array}{c}\mathrm{CO}_{2} \\
\text { emissions }(\mathrm{Mt})\end{array}$ & $\begin{array}{c}\text { Population } \\
\left(10^{6}\right)\end{array}$ & $\begin{array}{c}\text { GDP } \\
\left(10^{9}\right)\end{array}$ \\
\hline Bahrain & 22.88 & 26.18 & 26.69 & 1.36 & 29.95 \\
KSA & 622.4 & 290.9 & 506.6 & 30.9 & 649.6 \\
Qatar & 219.9 & 36.35 & 77.61 & 2.70 & 161.8 \\
Oman & 74.49 & 25.96 & 59.90 & 4.24 & 67.48 \\
UAE & 200.0 & 102.2 & 175.43 & 9.09 & 350.9 \\
Kuwait & 166.4 & 57.54 & 86.08 & 3.75 & 136.2 \\
Total & 1306.1 & 539.13 & 932.31 & 54.04 & 1395.93 \\
\hline
\end{tabular}


air pollutant such $\mathrm{SO}_{2}$ and $\mathrm{NO}_{\mathrm{x}}$ may also be expected to high in the region. Figure 6 shows a time series of $\mathrm{SO}_{2}$ levels from 2004 to 2014 for a given number of oil and gas processing power plants in selected GCC states. The amount of $\mathrm{SO}_{2}$ depends on the number of power plant, thus 10, 3, 2, 2 are number of power plants for Saudi Arabia, Qatar, Kuwait and UAE respectively.

Also, a detailed air pollution load assessments (APL) were carried out in three GCC countries (Bahrain, Kuwait and Qatar), and results shows that vehicles and power plants are the major sources of fine $\mathrm{PM}$ emissions $\left(\mathrm{PM}_{10}\right.$ and $\left.\mathrm{PM}_{2.5}\right)$. The emission sources of $\mathrm{SO}_{2}, \mathrm{NO}_{\mathrm{x}}, \mathrm{VOC}$ and $\mathrm{CO}$ were due the industries, refineries, and power plants activities. According to Global Burden Disease Study and World Health Organization, 773 deaths annually may be due to $\mathrm{PM}_{2.5}$ (Nabar, 2015). Analysis of the mean tropospheric $\mathrm{NO}_{2}$ data indicates high $\mathrm{NO}_{2}$ concentration at the major cities of Riyadh and Jeddah (KSA), Abu Dhabi and Dubai (UAE), Kuwait City, Qatar and Bahrain. $\mathrm{NO}_{2}$ concentration was averagely lower in Oman (Farahat, 2016).

\section{Transboundary Air Pollution Control Guidelines for GCC}

World Bank has suggested that the developing countries should capitalize on the experience of the industrialized countries to move directly to market-based instruments to control pollution (Tietenberg \& Lewis 2012). The Convention on Long Range Transboundary Air Pollution (LRTAP) is one of the main corner stones for protecting the environment as pollutants can travel several thousand kilometers before deposition and damage occurs. GCC states would not have difficulties solving air pollution problems because tools for transboundary air pollution control has already been developed by nations such U.S, Europe, Canada .However, the following recommendation can help reduce trans-boundary air pollution problems among GCC states;

- Efforts to establish research orientations and institutional capacities in management and monitoring of $\mathrm{SO}_{2}, \mathrm{NO}_{\mathrm{x}}, \mathrm{PM}_{10}$, and $\mathrm{PM}_{2.5}$.

- The need for capacity building and, ground based monitoring systems and networks for proper operation and strategic decision support.

- The need for quality control and quality assurance and modeling tools.

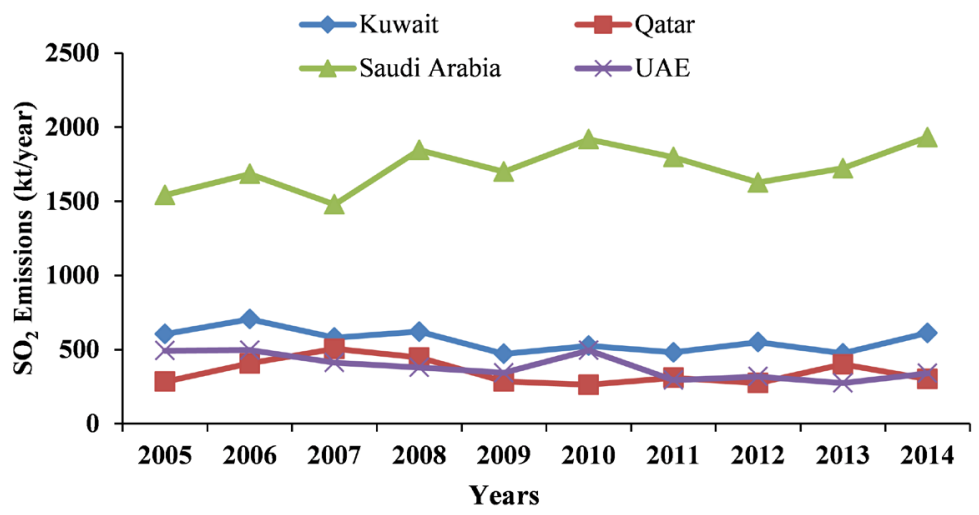

Figure 6. Time series of $\mathrm{SO}_{2}$ emissions (kt/year) in GCC of power plants (NASA 2017). 
- Application of satellite systems for earth observation of air pollution has been recently been introduced for monitoring and quantification of transboundary air pollution transport.

- Application of market based programs such cap and trade and emission trading instruments among the member states.

- Technological transfer among member states.

\section{Conclusion and Recommendations}

Regional cooperation through policies formulations and implementations could help address greenhouse emission and other acidic gases in the region. However, in the order to achieve the above cooperation, the following issues need to be addressed:

- Disparities among countries in terms of industrial location and $\mathrm{SO}_{2}, \mathrm{NO}_{\mathrm{x}}$ reduction potential;

- Variations in already existing policies and institutional capacities;

- Equal sharing of abatement cost;

- Regional and political differences.

The above recommendations are imperative as current developing countries (GCC) will face intensified environmental problems such as $\mathrm{SO}_{2}, \mathrm{NO}_{x}, \mathrm{PM}_{10}$, and $\mathrm{PM}_{2.5}$ emissions due to population growth, economic development, and rapid urbanization. Substantial reduction in Sulphur emissions in US-Canada, Japan-China and Europe shows that complex environmental problems can be managed even when pollutants cross borders through application of cost-effective, flexible and appropriate policy measures. This implies that GCC states formulate air pollution policies which could set ceilings to emissions produced by each country especially in power and oil industries. Also, emission trading system and adoption of air pollution control technologies could be adopted to reduce the levels in the region as well. However, in order to ensure full compliance of the suggested measures, effective air pollution monitoring program across the region needs to be developed.

\section{Conflicts of Interest}

The authors declare no conflicts of interest regarding the publication of this paper.

\section{References}

Atalay, Y., Biermann, F., \& Kalfagianni, A. (2016). Adoption of Renewable Energy Technologies in Oil-Rich Countries: Explaining Policy Variation in the Gulf Cooperation Council States. Renewable Energy, 85, 206-214. https://doi.org/10.1016/j.renene.2015.06.045

Bachmann, T. M., \& van der Kamp, J. (2014). Environmental Cost-Benefit Analysis and the EU (European Union) Industrial Emissions Directive: Exploring the Societal Efficiency of a DeNOx Retrofit at a Coal-Fired Power Plant. Energy, 68, 125-139. https://doi.org/10.1016/j.energy.2014.02.051

Bhutto, A. W., Bazmi, A. A., Zahedi, G., \& Klemeš, J. J. (2014). A Review of Progress in 
Renewable Energy Implementation in the Gulf Cooperation Council Countries. Journal of Cleaner Production, 71, 168-180. https://doi.org/10.1016/j.jclepro.2013.12.073

Brunekreef, B., \& Holgate, S. T. (2002). Air Pollution and Health. The Lancet, 360, 1233-1242. https://doi.org/10.1016/S0140-6736(02)11274-8

Chavez-Baeza, C., \& Sheinbaum-Pardo, C. (2014). Sustainable Passenger Road Transport Scenarios to Reduce Fuel Consumption, Air Pollutants and GHG (Green House Gas) Emissions in the Mexico City Metropolitan Area. Energy, 66, 624-634. https://doi.org/10.1016/j.energy.2013.12.047

Dong, L., Dong, H., Fujita, T., Geng, Y., \& Fujii, M. (2015). Cost-Effectiveness Analysis of China's Sulfur Dioxide Control Strategy at the Regional Level: Regional Disparity, Inequity and Future Challenges. Journal of Cleaner Production, 90, 345-359. https://doi.org/10.1016/j.jclepro.2014.10.101

EEA (2017). European Environment Agency's Home Page. European Environment Agency. http://www.eea.europa.eu

Ellerman, A. D. (2002). Markets for Clean Air: The U.S. Acid Rain Program (p. 32). Cambridge: Cambridge University Press.

Environment Canada (2017). Environment and Climate Change Canada-Air-Acid Rain. https://www.ec.gc.ca/air/default.asp?lang=En\&n=AA1521C2-1

Farahat, A. (2016). Air Pollution in the Arabian Peninsula (Saudi Arabia, the United Arab Emirates, Kuwait, Qatar, Bahrain, and Oman): Causes, Effects, and Aerosol Categorization. Arabian Journal of Geosciences, 9, 196. https://doi.org/10.1007/s12517-015-2203-y

Hitaj, C., \& Stocking, A. (2016). Market Efficiency and the U.S. Market for Sulfur Dioxide Allowances. Energy Economics, 55, 135-147. https://doi.org/10.1016/j.eneco.2016.01.009

IEA (2013). Non-Member Countries. http://www.iea.org/countries/non-membercountries

IJC (2014). AQA Report. International Joint Commission. https://www.ijc.org/sites/default/files/2018-08/AQA-Report-2014-ENG.pdf

Kanada, M. et al. (2013). Regional Disparity and Cost-Effective $\mathrm{SO}_{2}$ Pollution Control in China: A Case Study in 5 Mega-Cities. Energy Policy, 61, 1322-1331. https://doi.org/10.1016/j.enpol.2013.05.105

Krug, E., \& Frink, C. (2010). Acid Rain on Acid Soil: A New Perspective. Science, 221, 520-525. https://doi.org/10.1126/science.221.4610.520

Kuklinska, K., Wolska, L., \& Namiesnik, J. (2015). Air Quality Policy in the U.S. and the EU-A Review. Atmospheric Pollution Research, 6, 129-137. https://doi.org/10.5094/APR.2015.015

Landgrebe, R., Lipchin, C., \& Dzneladze, M. (2008). Convergence with EU Air Protection Policies-Short Guide for ENP Partners and Russia. Short Guide: EU Air Policy.

Larssen, T., \& Carmichael, G. R. (2000). Acid Rain and Acidification in China: The Importance of Base Cation Deposition. Environmental Pollution, 110, 89-102. https://doi.org/10.1016/S0269-7491(99)00279-1

Lee, C.-Y., \& Zhou, P. (2015). Directional Shadow Price Estimation of $\mathrm{CO}_{2}, \mathrm{SO}_{2}$ and $\mathrm{NO}_{\mathrm{x}}$ in the United States Coal Power Industry 1990-2010. Energy Economics, 51, 493-502. https://doi.org/10.1016/j.eneco.2015.08.010

Lekeshmanaswamy, M. (2012). Impact of Neochetina eichhorniae Warner on Biological Control of Water Hyacinth (Eichhornia crassipes (Mart.) Solms.) of Singanallur Pond, Coimbatore, TamilNadu, India. 
Li, X., Wu, X., \& Zhang, F. (2015). A Method for Analyzing Pollution Control Policies: Application to $\mathrm{SO}_{2}$ Emissions in China. Energy Economics, 49, 451-459. https://doi.org/10.1016/j.eneco.2015.03.015

Menz, F. C., \& Seip, H. M. (2004). Acid Rain in Europe and the United States: An Update. Environmental Science \& Policy, 7, 253-265.

https://doi.org/10.1016/j.envsci.2004.05.005

Mokhtar, M. M., Hassim, M. H., \& Taib, R. M. (2014). Health Risk Assessment of Emissions from a Coal-Fired Power Plant Using AERMOD Modeling. Process Safety and Environmental Protection, 92, 476-485. https://doi.org/10.1016/j.psep.2014.05.008

Nabar, H. (2015). Air Pollution; Evidence from the Gulf Environmental Partnership and Action Program, Middle East and North Africa Region GCC Country Unit, WHO.

Nagase, Y., \& Silva, E. C. D. (2007). Acid Rain in China and Japan: A Game-Theoretic Analysis. Regional Science and Urban Economics, 37, 100-120. https://doi.org/10.1016/j.regsciurbeco.2006.08.001

Nam, K.-M., Waugh, C. J., Paltsev, S., Reilly, J., Mand, V., \& Karplus, J. (2013). Carbon Co-Benefits of Tighter $\mathrm{SO}_{2}$ and $\mathrm{NO}_{x}$ Regulations in China. Global Environmental Change, 23, 1648-1661. https://doi.org/10.1016/j.gloenvcha.2013.09.003

NASA (2017). Global Sulfur Dioxide Monitoring. https://so2.gsfc.nasa.gov

Ohshita, S., \& Ortolano, L. (2012). The Profit and Pitfalls of Japanese Cleaner Coal Technology Transfer to Chin. International Journal of Technology Transfer and Commercialisation, $1,56-81$.

Rafindadi, A. A., Muye, I. M., \& Kaita, R. A. (2018). The Effects of FDI and Energy Consumption on Environmental Pollution in Predominantly Resource-Based Economies of the GCC. Sustainable Energy Technologies and Assessments, 25, 126-137. https://doi.org/10.1016/j.seta.2017.12.008

Rótulo Decuadra, D. E., \& Puppim de Oliveira, J. A. (2008). International Environmental Agreements between Developing Countries Only: Learning from the Brazil-Uruguay Case over the Suspicion of Acid Rain. International Environmental Agreements: Politics, Law and Economics, 8, 389-408. https://doi.org/10.1007/s10784-008-9084-4

Schmieman, E. C., van Ierland, E. C., \& Hordijk, L. (2002). Dynamic Efficiency with Multi-Pollutants and Multi-Targets: The Case of Acidification and Tropospheric Ozone Formation in Europe. Environmental and Resource Economics, 23, 133-148. https://doi.org/10.1023/A:1021234423189

Streeter, J. L. (2016). Adoption of $\mathrm{SO}_{2}$ Emission Control Technologies-An Application of Survival Analysis. Energy Policy, 90, 16-23. https://doi.org/10.1016/j.enpol.2015.11.035

Tietenberg, T., \& Lewis, L. (2012). Environmental and Natural Resources Economics (9th ed., p. 375). London: Pearson Education, Inc.

US EPA (2016). Screening Models. https://www3.epa.gov/ttn/scram/dispersion_screening.htm

US EPA (2017a). Air Pollution: Current and Future Challenges. https://www.epa.gov/clean-air-act-overview/air-pollution-current-and-future-challeng $\underline{\text { es }}$

US EPA (2017b). Acid Rain. https://www.epa.gov/acidrain

World Bank (2016). The Cost of Air Pollution: Strengthening the Economic Case for Action. World Bank Group. 